\title{
Actually, a picture is worth less than 45 words: Narratives produce more false memories than photographs do
}

\author{
MARYANNE GARRY and KIMBERLEY A. WADE \\ Victoria University of Wellington, Wellington, New Zealand
}

\begin{abstract}
Most memory "implantation" studies have elicited false memories by using fake narratives. Recently, Wade, Garry, Read, and Lindsay (2002) showed that doctored photographs can be used to create false childhood memories in adults. Fifty percent of Wade et al.'s sample reported details of taking a childhood hot air balloon ride, although they had never been in a balloon. In this experiment, we investigated whether photos or narratives influence memory more than the other. We exposed subjects to either a fake photograph or a fake narrative of a childhood hot air balloon ride. Subjects tried to remember the false event and three real events over 1 week. Narratives were more likely to produce false memory reports than were photos. We offer a fluency-based account of our results and suggest that narratives promote more familiarity in subjects than do photographs.
\end{abstract}

In this digital age, we know that the saying "the camera never lies" is not true. Of course, it never really was true. Photographs have long been used to modify collective memory. Stalin, for example, cut the out-of-favor from official photographs (King, 1997). Not only can doctored photos alter collective memory; new research shows that they can distort our personal memories. Recently, Wade, Garry, Read, and Lindsay (2002) adapted Loftus and Pickrell's (1995) narrative-based paradigm. Wade et al. showed adults a mix of real childhood photos and one fake photo depicting each subject in a hot air balloon; $50 \%$ eventually remembered details of the trip. This rate is much higher than that seen in the narrative literature, where narrative "implantation" studies have produced a mean weighted false report rate of $31 \%$ (see Lindsay, Hagen, Read, Wade, \& Garry, 2004). In this article, we address the question of whether false photographs or false narratives are a more powerful tool for creating false memories.

There are many reasons to predict that photographs should be better at creating memories for false events. Intuitively, we think that photographs are better at helping us to remember genuine events. We surveyed $30 \mathrm{col}-$ leagues and asked, "Would a photograph or a written description of a childhood event be better at jogging your

We are grateful to the Royal Society of New Zealand and the Marsden Fund for their generous support of this research under Grant VUW205. K.A.W. was supported by a VUW Targeted PhD scholarship. Our thanks to Stefanie Sharman, Beth Loftus, Don Read, Steve Lindsay, the Cognitive Workshop group, Dan Bernstein, and two anonymous reviewers for their helpful comments. K.A.W. is now at the University of Warwick, Coventry, England. Correspondence should be addressed to M. Garry, School of Psychology, Victoria University of Wellington, P.O. Box 600, Wellington, New Zealand (e-mail: maryanne.garry@vuw.ac.nz). memory?" All 30 chose photographs. Scientific research also predicts that photos should influence memory more than words. Photographs should help people visualize events, and myriad studies show that visualizing something helps recall (Dobson \& Markham, 1993; Paivio, 1971). In addition, research shows that we do not simply adopt a false suggestion without evaluating the credibility of the source of that suggestion (Dodd \& Bradshaw, 1980; Johnson, Hashtroudi, \& Lindsay, 1993; Vornik, Sharman, \& Garry, 2003). Because we have a misplaced but pervasive faith in the objective quality of photographs (Mided, 1998), we view them as more credible than narrative descriptions. Indeed, we have all swapped childhood stories at some family gathering, only to have a dispute arise over which sibling actually did what. We do not, however, have those disputes about photographs.

We might conclude, then, on the basis of research and everyday experience, that false photos would cultivate false memories better than narratives would. However, other research suggests that narratives would work better. That research shows that we consider how familiar an event feels when judging whether it really happened.

In general, the more familiar a memory is, the more likely one is to conclude that the event was real (Jacoby, Kelley, \& Dywan, 1989; Johnson et al., 1993). However, different factors can promote a feeling of familiarity, such as the ease with which information is remembered. This ease-of-remembering - or fluency - can be misattributed to prior experience, which in turn causes people to have memory distortions (Jacoby et al., 1989; Whittlesea, 1993).

Bernstein and colleagues (Bernstein, Whittlesea, \& Loftus, 2002; Nourkova, Bernstein, \& Loftus, 2004) have shown how increased fluency can cause false memories. Bernstein et al.'s subjects rated their confidence 
that a list of experiences had happened to them (for example, broke a window playing ball), but for some subjects a central word was scrambled (broke a nwidwo playing ball). Initially, the meaningless scrambled word is processed with little fluency, but the context helps subjects make sense of it and process it more easily. Its fluency increases, and subjects attribute the resulting familiarity to having had the experience. More recently, Kronlund and Whittlesea (2005) showed that subjects who processed words deeply during encoding were more likely to report seeing them twice when they were presented only once. Presumably, the richer processing enhanced subjects' fluency for the words, so that when asked to remember the words later, they had the illusion of repetition. Which medium then, photographs or narratives, should be better at increasing fluency? Because narratives allow and even demand that subjects generate their own details, narratives should give subjects freedom to generate their own images, incorporate personal knowledge, and require deeper processing. By contrast, photographs impose more constraints on imagination because they depict specific details, people, and settings (see also Hyman, Husband, \& Billings, 1995, who showed that subjects who incorporated self-knowledge into their imagery were more likely to develop false memories). Taken together, research suggests that narratives should establish more familiarity than should photos and make subjects more likely to falsely remember events.

In short, theoretical reasoning leads to different predictions about the relative power of photographs and narratives. We pitted doctored photos against false narratives to investigate which was more powerful in eliciting false memories.

\section{METHOD}

\section{Subjects}

Forty-four introductory psychology students each recruited a family member subject who had not experienced the false event. We randomly allocated subjects to either the false photo or false narrative condition. The subjects ranged in age from 18 to 30 years $\left(M_{\text {photo }}=21.7, S D=3.4 ; M_{\text {narrative }}=21.5, S D=3.6\right)$ and received a $\$ 25$ voucher for participating.

\section{Procedure}

For each subject, we created a booklet containing photos and narratives, with three real events and one false event. Event 3 was always the false event, either a photo or a narrative. To prevent order effects, we counterbalanced the medium of Event 1 and Event 2 within each condition (see Figure 1). ${ }^{1}$

Creating true events. Confederates gave us photographs of moderately significant events (school functions, family trips) showing the subject between the ages of 4 and 8 . We digitized the photos and printed them in grayscale at $300 \mathrm{dpi}$ and $18 \times 16 \mathrm{~cm}$. Confederates also helped us to create two true narratives, 2-3 sentences long. True narratives described the event, the subject's age, the people involved, the approximate year, and the location.

Creating false events. For photo subjects, we used Adobe Photoshop 7.0 to produce an image of a childhood hot air balloon ride (see Figure 2 and Wade et al., 2002). The photograph always depicted the subject and at least one family member.

For narrative subjects, we personalized a generic 45-word description of the balloon ride. We took steps to equate the informa- tion in both mediums, showing eight judges 2 subjects' balloon photos from the Wade et al. (2002) study. Judges answered four questions: "Who is in the photo?" "What are they doing?" "Where are they doing it?" and "Can you date the photo?" They were asked to write anything else they could infer.

Judges provided a total of 25 details. We took the most frequently reported details - reported by at least six $(75 \%)$ of the judges - to create the core of our false narrative. We then customized the narrative for individual subjects by adding personal details that would have been apparent had they been assigned to the photo condition (approximate age, family member[s] involved). We obtained a photorealistic printer that emphasized light and shadows. When we asked eight new judges in what season they thought the balloon ride had occurred, six said the shadows suggested late autumn/early winter (May/June in New Zealand). Thus, we noted the season in the narrative. Finally, we incorporated the subject's hometown into the narrative to make it comparable to true narratives. The final version of the narrative was:

When you were between [4-6] years old, you and your [dad] went up in a hot air balloon in [Wanganui]. You didn't go far off the ground because the ropes anchoring the balloon were still attached. It was around May/June; a colder season.

Interviews. We used Wade et al.'s (2002) interview procedure. The subjects attended three interviews over 1 week. Interviews 1 and 3 were audiotaped.

Interview 1. The subjects were told that the study was about childhood reminiscence. They reported everything they could recall about each event in turn. If they could not recall an event (usually the false event), we reassured them that long-ago events were often difficult to recall and asked them to spend a minute concentrating and trying to remember. If the subjects still failed to recall an event (usually the false event), we encouraged them to engage in guided imagery for $1 \mathrm{~min}$, to close their eyes and try to picture themselves being back in a hot air balloon.

When the subjects could recall no more, we measured their confidence that each event actually occurred on a 7-point scale from 1 ( $0 \%$ confident $)$ to 7 (100\% confident). We also adapted a questionnaire by Berntsen, Willert, and Rubin (2003) to measure the qualities of the subjects' memories. The subjects indicated on a 7-point scale $(1=$ low, $7=$ high $)$ whether they could (1) relive the original event in their mind; (2) see the event in their mind; (3) hear the event in their mind; (4) feel the original emotions associated with the event; (5) remember the event rather than just knowing it happened; (6) remember the event as a coherent story; (7) believe the event occurred the way in which they remember it; and (8) talked/ thought about the event in the past.

We asked the subjects not to discuss childhood events with family members or to review childhood photographs until the study was over, and to try to remember more about the events. They took copies of their booklets home to remind them to think about the events daily.

Interview 2. The subjects returned for the second interview 3-4 days later to report any additional event details. If necessary, we repeated guided imagery instructions from Interview 1 . The subjects again answered the qualitative-detail questions.

Interview 3. The final interview was conducted 1 week after Interview 1 and followed the same procedure. Prior to debriefing, we asked the subjects (1) how often they had thought about the events during the study; (2) whether they had discussed the events with others; and (3) which event medium (photo vs. narrative) was better at "jogging" their memory. Finally, the subjects were debriefed.

\section{RESULTS AND DISCUSSION}

Most subjects expressed surprise during debriefing when they were told that the balloon photo was a fake. These comments suggested that subjects believed that 
Event 3-

Event $1 \quad$ Event $2 \quad$ False event $\quad$ Event 4

Narrative
group

\begin{tabular}{|c|c|c|c|}
\hline $\begin{array}{l}\text { Photo } \\
\text { group }\end{array}$ & & 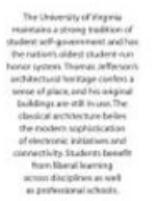 & 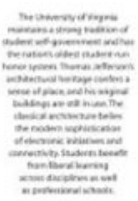 \\
\hline $\begin{array}{l}\text { Photo } \\
\text { group }\end{array}$ & 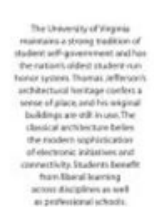 & & 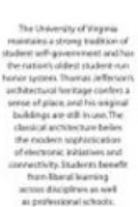 \\
\hline
\end{tabular}

Figure 1. Counterbalancing design for event booklet.

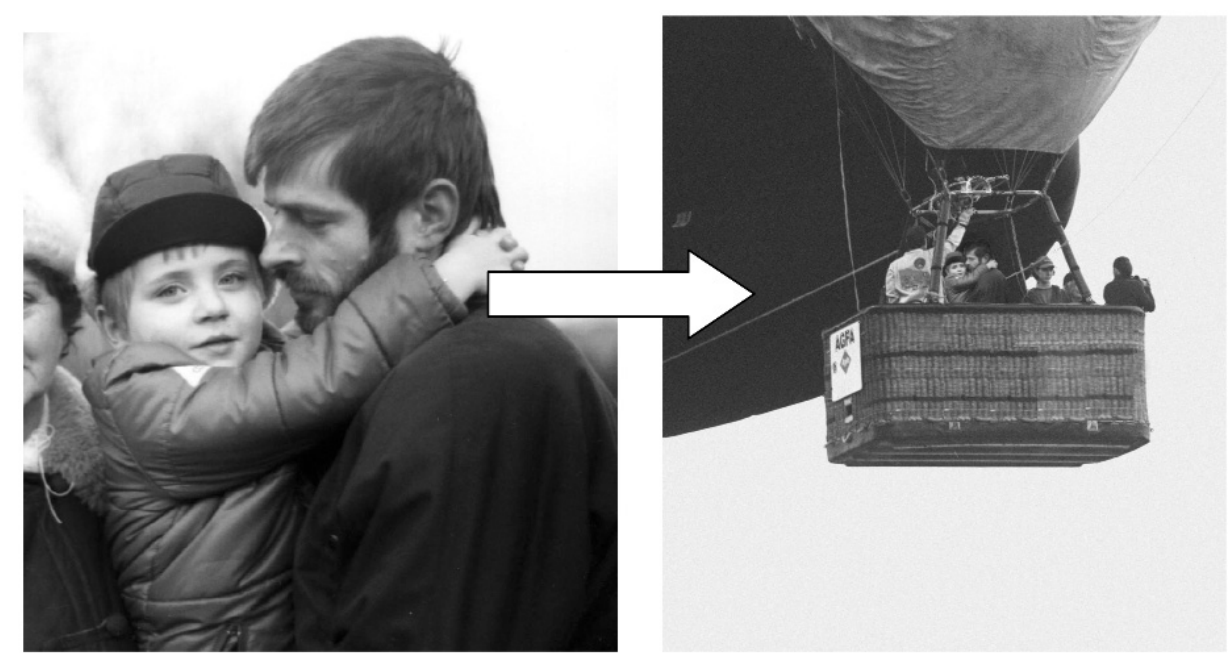

Figure 2. Process of doctoring a photo: source photo (left panel) and doctored photo (right panel). 
the false event had occurred. In addition, three judges who read interview transcripts (which were disguised to conceal condition) determined that $71 \%$ believed that they had taken the hot air balloon ride. Together, these results suggest that the false memories in this study were not the result of subjects' trying to please the interviewer.

\section{Event Recall}

Subjects' recall of true events was near ceiling, 97\% by Interview 3. For the false event, three judges (again, blind to the photo/narrative assignment) used Lindsay et al.'s (2004) criteria to rate whether each subject reported (1) no images, (2) images only, or (3) memories of the false event. To be put in the images only category, subjects' reports must have described images associated with the false event, but those images need not have been experienced as memories of the event per se. The memories category required subjects to report remembering the false event and details about the event that were not depicted in the doctored photograph or outlined in the false narrative. Judges concurred on $82 \%$ of categorizations with a high confidence rate of $2.8(S D=0.5 ; 1=$ low confidence, $3=$ high confidence); they resolved disputes by discussion. ${ }^{2}$ When asked to indicate which condition they believed subjects were in, judges were at chance $[t(43)=.74, p>.05]$.

The primary question in this study was whether false photos or false narratives were more likely to elicit false memories. As Figure 3 shows, narrative subjects were more likely to generate some false information-either images or memories - about the event $\left[\chi^{2}(1, N=44)=\right.$ $5.10, p=.03]$. At Interview $3,82 \%$ of the narrative sub- jects reported at least some information about the hot air balloon ride; $50 \%$ of the photo subjects did so (see Table 1 for sample reports). No subjects reported false information at Interview 1, prior to guided imagery, and the false recall rate of $50 \%$ in the photo condition replicates that in Wade et al. (2002).

There are three important findings from the narrative group. First, their false recall rate was higher than that in any peer-reviewed memory-implantation type study, both at Interview 1 (after guided imagery) and at Interview 3. Second, photo subjects tended to remain in the same memory category across interviews, whereas narrative subjects were more likely to shift categories $[41 \%$ vs. $\left.73 \% ; \chi^{2}(1, N=44)=4.63, p=.03\right]$. Third, when subjects changed memory categories, more narrative subjects tended to move toward creating memories than did photo subjects [55\% vs. $\left.27 \% ; \chi^{2}(1, N=44)=3.44, p=.06\right]$. These results suggest that narratives are better than photographs at eliciting false memories.

\section{Qualities of the False Reports}

If narratives facilitate imagination more than do photographs, allowing subjects to incorporate personal knowledge, we should see improving quality in aspects of narrative subjects' memories and a greater tendency to speculate about where the balloon ride had happened.

Quality of memories. As Table 2 shows, narrative subjects tended to report that the quality of their memories improved, although not significantly. However, a clearer picture emerges when we look at the data in a different way. For each of the eight measures, we calculated the percentage of subjects who reported increased rat-

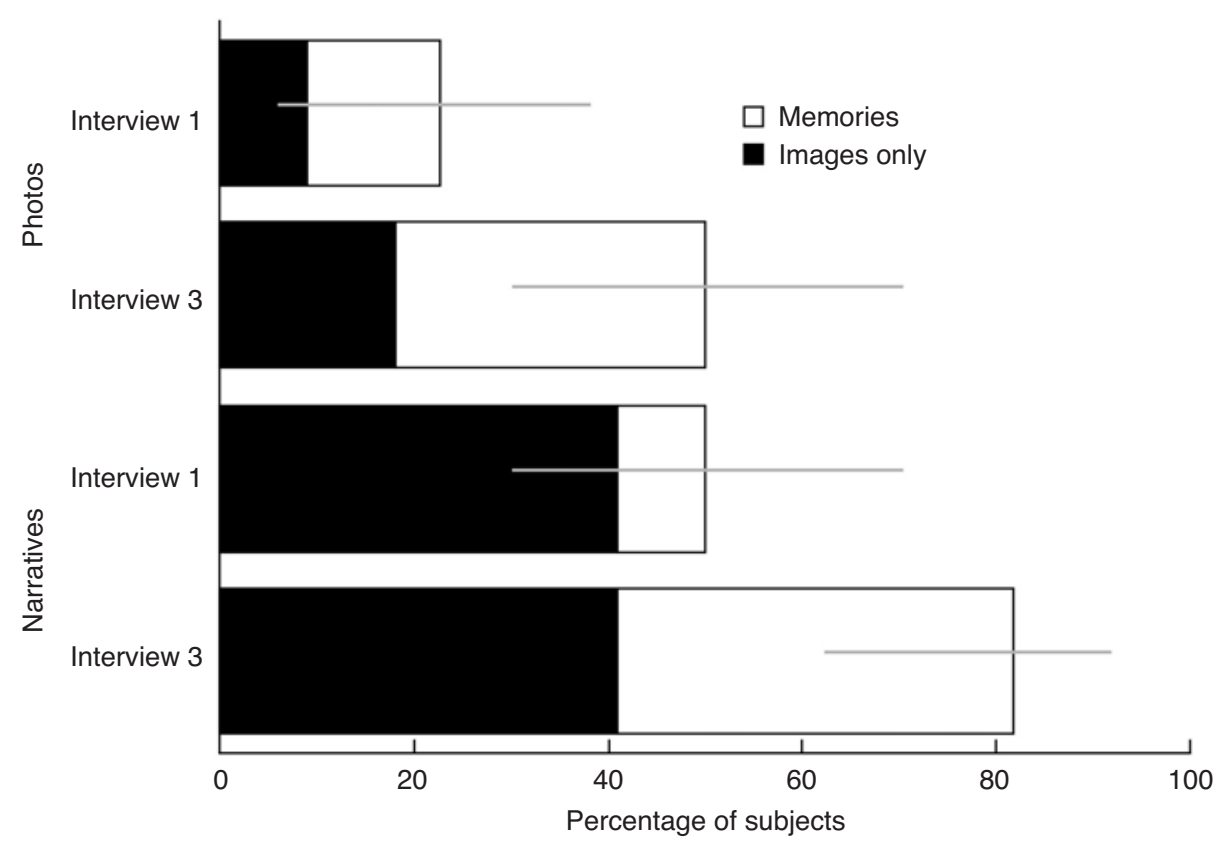

Figure 3. Percentage of subjects who reported images or memories by medium and interview. Error bars denote $95 \%$ confidence intervals based on individual cell means. 
Table 1

Sample False Memory Reports From Photo and Narrative Subjects

\begin{tabular}{|c|c|c|}
\hline \multirow[b]{2}{*}{ Condition } & \multicolumn{2}{|c|}{ Memory Type } \\
\hline & Memories & Images Only \\
\hline Narrative & $\begin{array}{l}\text { Um. Okay I think it was at the XXX School } \\
\text { Fair. Um, and I didn't want to go up in a } \\
\text { balloon. Um. I vaguely remember being in } \\
\text { it and my mum sort of telling me that we } \\
\text { weren't actually going to fly away because } \\
\text { there were ropes holding it. I didn't believe } \\
\text { her and I was really scared that we were } \\
\text { going to fly away and be stuck up in the air. } \\
\text { And my dad was laughing but I was really } \\
\text { mad at him because I just wanted to get out. } \\
\text { I was really, really scared. Um, and it was } \\
\text { cold and the wind was blowing in my face } \\
\text { and there were quite a few people around. } \\
\text { I could see quite a few people. }\end{array}$ & $\begin{array}{l}\text { Yeah, I can definitely get a picture of it, yeah. } \\
\text { Yeah, it probably would have been windy out } \\
\text { there, lots of people at the carnival and um, } \\
\text { yeah, sort of, cuz I can see the balloon as } \\
\text { having one of those sort of basket bits at the } \\
\text { bottom, um, can't remember too much more. }\end{array}$ \\
\hline Photo & $\begin{array}{l}\text { We're in this hot air balloon. Um, it was a } \\
\text { nice day, sunny day. Not sure if it was like a } \\
\text { slow, cool breeze coming from that } \\
\text { direction. Cuz the sea is over there. Um, as } \\
\text { I look straight I can see sort of, there's like } \\
\text { a park below us and in the distance over } \\
\text { there there's sort of like Palm trees, you } \\
\text { know those Palm tree things. Um, I can see } \\
\text { mum down by the car. She's like watching } \\
\text { us but she's not comfortable watching us. } \\
\text { She's scared of heights. So I had a bit of a } \\
\text { laugh about that. Um, and yeah, the car park } \\
\text { is over there [subject points ahead] sort of } \\
\text { towards the back. Um, that's probably all I } \\
\text { can tell you. We're not very high off the } \\
\text { ground . . . And we're not really moving } \\
\text { either, we're just sort of hovering up above } \\
\text { the park. }\end{array}$ & $\begin{array}{l}\text { I sort of feel like I can picture a big crowd ... } \\
\text { Yeah. Sort of in, outside the balloon but it's } \\
\text { only very vague. I think, and I can, I can sort of } \\
\text { feel how it would feel to be in a hot air balloon } \\
\text { but I know I went on one when I was older and } \\
\text { that's probably what I'm remembering. I can't } \\
\text { really . . I can't remember that particular } \\
\text { experience. I sort of feel as if I would have } \\
\text { been quite scared. But that's all. }\end{array}$ \\
\hline
\end{tabular}

ings from Interview 1 to Interview 3 . Figure 4 shows that in seven out of eight measures, more narrative subjects experienced increasing memory quality compared with photo subjects; a paired $t$ test treating measures as cases was significant [mean difference $=15.38 \% ; t(7)=4.79$, $p<.01, S E=3.21]$. These two ways of examining the data suggest that narratives enhanced subjects' memories of the event more than did photographs.

Speculation. If narratives provide greater support for speculation, narrative subjects should be more likely to provide details about where the balloon ride took place. Three judges determined whether subjects described a location (with 93\% agreement). Narrative subjects were more likely than photo subjects to provide a specific location $\left[14 \%\right.$ vs. $\left.0 \% ; \chi^{2}(1, N=44)=4.38, p=.04\right]$.

Taken together, these results support the idea that false narratives gave more free rein to the imagination and permitted more infusing of personal knowledge. More tentative evidence comes from the quality ratings that subjects gave true memories. Table 3 shows that as with false events, true narratives produced higher ratings than did true photographs. We are reluctant to draw too much from these data because (1) true events were idiosyncratic across subjects, and (2) the distribution of true photos and narratives is unbalanced. However, the rat- ings for the true events illustrate the same sort of pattern as the false events.

\section{Confidence}

Subjects who generated some information about the balloon ride were similarly confident that it had occurred, regardless of medium $\left[M_{\text {narrative }}=35 \%(S D=\right.$ $27)$ vs. $\left.M_{\text {photo }}=29 \%(S D=16) ; t(27)=.26, p=.78\right]$. What are we to make of this null effect for confidence?

Table 2

Subjects' Mean Ratings of Their Memory Quality for the False Events as a Function of Medium and Interview

\begin{tabular}{|c|c|c|c|c|c|c|c|c|}
\hline \multirow[b]{3}{*}{ Measure } & \multicolumn{4}{|c|}{ False Photos } & \multicolumn{4}{|c|}{ False Narratives } \\
\hline & \multicolumn{2}{|c|}{ Interview 1} & \multicolumn{2}{|c|}{ Interview 3} & \multicolumn{2}{|c|}{ Interview 1} & \multicolumn{2}{|c|}{ Interview } \\
\hline & $M$ & $S D$ & $M$ & $S D$ & $M$ & $S D$ & $M$ & $S D$ \\
\hline elive & 1.50 & 1.01 & 1.45 & 0.67 & 1.23 & 0.53 & 1.95 & 1.43 \\
\hline ee & & & & & & & & 0.9 \\
\hline ear & & & & & & & & 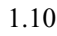 \\
\hline & & 0.8 & 1.4 & & & 0.75 & & .3 \\
\hline r & & 1.1 & 1.3 & 0.79 & 1.1 & 0.50 & 1. & 1.0 \\
\hline tory & 1.23 & 0.61 & 1.36 & 0.66 & 1.18 & 0.50 & 1.59 & 0.8 \\
\hline Believe & 2.14 & 1.39 & 2.14 & 0.99 & 2.18 & 1.18 & 2.32 & 1.43 \\
\hline Talked/thought & 1.23 & 0.87 & 1.23 & 0.53 & 1.09 & 0.43 & 1.45 & 0.86 \\
\hline
\end{tabular}

Note-1 = low, 7 = high 


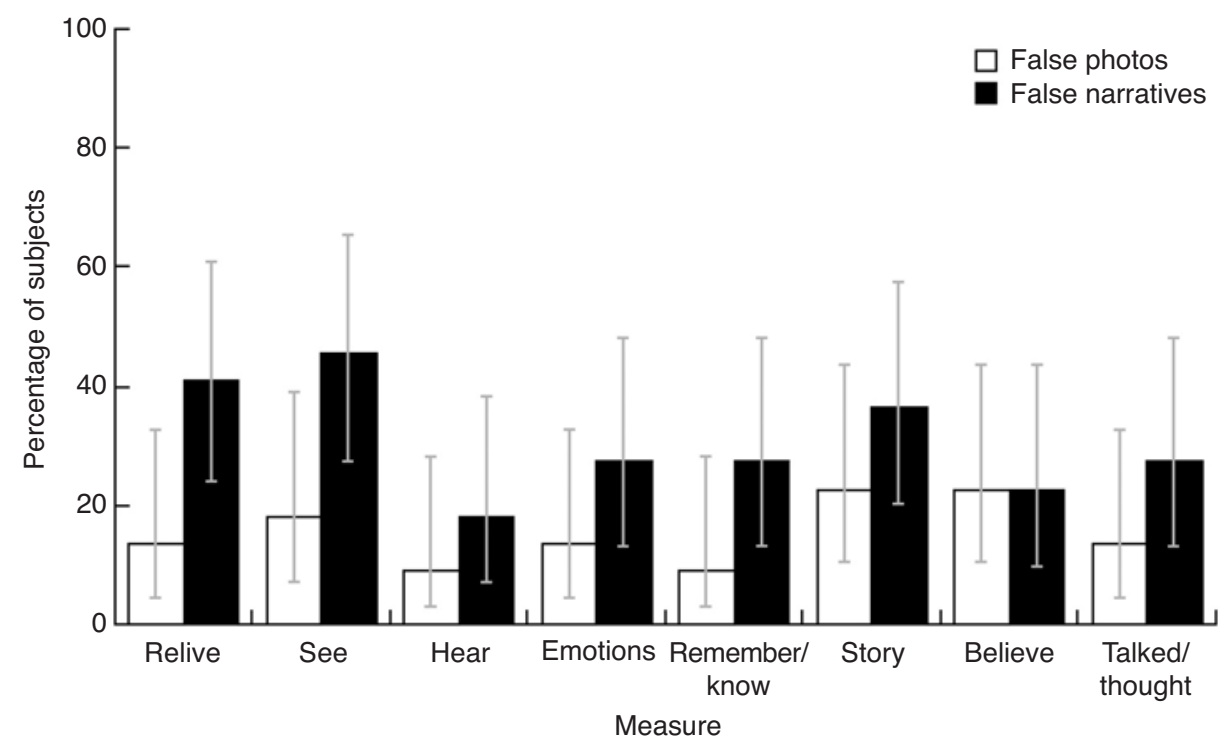

Figure 4. Percentage of subjects who increased on each measure as a function of event medium (photo vs. narrative). Error bars denote $95 \%$ confidence intervals based on individual cell means.

On the one hand, we might conclude that confidence alone has no mediating role in the formation of false memories. On the other hand, this confidence question does not tap into a qualitative aspect of memory: it asks, simply, how confident subjects are that the event occurred. Confidence was low compared with real events $(M=86 \%, S D=24)$ and in line with (although somewhat lower than) confidence in other implantation studies. Why should confidence be rather low even in subjects who remember at least something about the balloon ride? We suspect that asking subjects to evaluate their memories on nine dimensions may have depressed their confidence. Introspection can influence one's judgments, reasoning, and memory (Wilson \& LaFleur, 1995; Wilson $\&$ Schooler, 1991). Likewise, asking subjects to evaluate their memories may have focused their attention on details that were difficult to reconcile with their memories and thus diminished their confidence. Such an outcome is all the more likely, given that subjects were comparing genuine and more familiar events with a false one.

Table 3

Subjects' Mean Ratings of Their Memory Quality for the True Events as a Function of Medium and Interview

\begin{tabular}{|c|c|c|c|c|c|c|c|c|}
\hline \multirow[b]{3}{*}{ Measure } & \multicolumn{4}{|c|}{ True Photos } & \multicolumn{4}{|c|}{ True Narratives } \\
\hline & \multicolumn{2}{|c|}{ Interview 1} & \multicolumn{2}{|c|}{ Interview 3} & \multicolumn{2}{|c|}{ Interview 1} & \multicolumn{2}{|c|}{ Interview 3} \\
\hline & $M$ & $S D$ & $M$ & $S D$ & $M$ & $S D$ & $M$ & $S D$ \\
\hline elive & & 1.6 & 3.6 & & & .66 & & 1.62 \\
\hline & & 1.66 & 4.3 & & 4.60 & 1.68 & & 1.4 \\
\hline Hear & & 1.72 & & & 2.83 & 1.66 & & 1.62 \\
\hline & & 1.8 & & & 3.7 & & 3.88 & 1.6 \\
\hline & & 2.0 & 4.5 & & 4.74 & 1.87 & 5.1 & 1.7 \\
\hline & & 1.86 & 3.85 & 1.87 & 3.98 & 2.02 & 4.48 & 1.8 \\
\hline Believe & 5.27 & 1.90 & 5.39 & 1.64 & 5.68 & 1.57 & 5.80 & 1.3 \\
\hline Talked/thought & 2.79 & 1.67 & 3.26 & 1.77 & 3.38 & 1.64 & 3.56 & 1.50 \\
\hline
\end{tabular}

Note-1 = low, $7=$ high .

\section{Memory Work}

We asked subjects how many times they worked at remembering the events during the study. Subjects who spent more time working at remembering the false event were marginally more likely to experience a false memory (Hyman \& Pentland, 1996; Read \& Lindsay, 2000). Those who remembered something about the event engaged in memory work $6.7(S D=3.9)$ times, and those who remembered nothing reported $5.5(S D=1.6)$ times $(p=.06)$. However, narrative and photo subjects did not engage in different amounts of memory work $\left[M_{\text {narrative }}=\right.$ $6.8(S D=4.0)$ vs. $\left.M_{\text {photo }}=5.8(S D=2.5), p=.30\right]$. Thus, the idea that narrative subjects worked harder at remembering the false event than did photo subjects does not adequately explain our findings.

\section{Photos Versus Narratives as Memory Joggers}

We asked subjects whether photographs or narratives were better at jogging their memories during the study. Interestingly, narrative subjects said that photos were better cues, whereas photo subjects said that narratives were better cues $\left[\chi^{2}(1, N=44)=19.49, p<.01 ; \Phi=\right.$ .67]. We suspect that this pattern is the result of an availability heuristic (Tversky \& Kahneman, 1973; Winkielman, Schwarz, \& Belli, 1998). Subjects may have decided which medium was better at jogging their memories by evaluating their recent and difficult experience in recalling the hot air balloon ride. Because everyone had difficulty remembering the false event at first, when faced with the forced choice between whether narratives or photos were better at jogging their memories, subjects might have attributed their memory difficulties to the inadequacy of the cues they were given. Thus, they might have reasoned that they would have remembered the event more easily if given the other medium. 
Considered as a whole, our results lead us to conclude that narratives influenced false memory development more than photographs did. One possible counterexplanation for these results could be that narrative subjects did not have more false memories but simply reported details that our judges thought sounded like false memories. In other words, they provided more details because the narrative lacked them, whereas photo subjects would not have felt obliged to simply parrot details in the photograph. Such a mechanism predicts that narrative subjects should have used more words to describe the false event. However, photo and narrative subjects used the same number of words $\left[M_{\text {narrative }}=156.9(S D=88.0)\right.$ vs. $\left.M_{\text {photo }}=134.1(S D=105.1) ; F<1\right]$. Thus, our results do not square with this counterexplanation.

Instead, our data fit with a fluency account of false memory development. Narratives demand more kinds of behaviors that increase fluency and thus elicit more false memories than do photographs. In the autobiographical memory literature, our results help to refine Mazzoni, Loftus, and Kirsch's (2001) model of false memory development. In their model, false memories develop if subjects first come to see the event as plausible, then come to believe that the event happened to them, and finally mistake their internally generated information for a real experience. How does the Mazzoni et al. three-step model apply to our data? We have no data on plausibility judgments, but we did find that subjects' confidence was the same in both conditions. Thus, we might infer that plausibility was also the same in both conditions. We might hypothesize, then, that something happens at step three to draw the power away from photographs and into narratives. That "something" could be related to fluency. If narratives make it easier for subjects to construct information about the event, that information will be processed more fluently, feel more familiar, and be more likely to be mistaken for a real experience. Future research should be directed at examining how different mediums of evidence can affect fluency.

Finally, researchers have become increasingly aware of the storylike nature of our personal experiences (Neisser, 1986; Pillemer, 1998; Singer \& Bluck, 2001). A narrative, whether true or false, flows with a purpose and tells a story. By contrast, a photograph is a snapshot of time, a memory atom. And, as the poet Muriel Rukeyser once observed, the universe is made of stories, not of atoms.

\section{REFERENCES}

Bernstein, D. M., Whittlesea, B. W. A., \& Loftus, E. F. (2002). Increasing confidence in remote autobiographical memory and general knowledge: Extensions of the revelation effect. Memory \& Cognition, 30, 432-438.

BerntSEN, D., Willert, M., \& Rubin, D. C. (2003). Splintered memories or vivid landmarks? Qualities and organization of traumatic memories with and without PTSD. Applied Cognitive Psychology, 17, 675-693.

DOBSON, M., \& MARKHAM, R. (1993). Imagery ability and source monitoring: Implications for eyewitness memory. British Journal of Psychology, 84, 111-118.

DoDD, D. H., \& BRADSHAW, J. M. (1980). Leading questions and mem- ory: Pragmatic constraints. Journal of Verbal Learning \& Verbal Behavior, 19, 695-704.

HYMAN, I. E., JR., \& BILlingS, F. J. (1998). Individual differences and the creation of false childhood memories. Memory, 6, 1-20.

Hyman, I. E., JR., Husband, T. H., \& Billings, F. J. (1995). False memories of childhood experiences. Applied Cognitive Psychology, 9, 181-197.

HYMAN, I. E., JR., \& Pentland, J. (1996). The role of mental imagery in the creation of false childhood memories. Journal of Memory \& Language, 35, 101-117.

JaCOBY, L. L., Kelley, C. M., \& Dywan, J. (1989). Memory attributions. In H. L. Roediger III \& F. I. M. Craik (Eds.), Varieties of memory and consciousness: Essays in honour of Endel Tulving (pp. 391422). Hillsdale, NJ: Erlbaum.

Johnson, M. K., Hashtroudi, S., \& Lindsay, D. S. (1993). Source monitoring. Psychological Bulletin, 114, 3-28.

KING, D. (1997). The commissar vanishes: The falsification of photographs and art in Stalin's Russia. New York: Metropolitan.

Kronlund, A., \& Whittlesea, B. W. A. (2005). Seeing double: Levels of processing can cause false memory. Canadian Journal of Experimental Psychology, 59, 11-16.

Lindsay, D. S., Hagen, L., Read, J. D., Wade, K. A., \& Garry, M. (2004). True photographs and false memories. Psychological Science, 15, 149-154.

LofTUS, E. F., \& PICKRell, J. E. (1995). The formation of false memories. Psychiatric Annals, 25, 720-725.

Mazzoni, G. A. L., Loftus, E. F., \& Kirsch, I. (2001). Changing beliefs about implausible autobiographical events: A little plausibility goes a long way. Journal of Experimental Psychology: Applied, 7, 51-59.

MIDED, J. (1998). The photographic image and the digital truth. Unpublished master's thesis, University of Sussex.

NEISSER, U. (1986). Nested structure in autobiographical memory. In D. C. Rubin (Ed.), Autobiographical memory (pp. 71-81). Cambridge: Cambridge University Press.

Nourkova, V., Bernstein, D. M., \& Loftus, E. F. (2004). Biography becomes autobiography: Distorting the subjective past. American Journal of Psychology, 117, 65-80.

PAIVIO, A. (1971). Imagery and deep structure in the recall of English nominalizations. Journal of Verbal Learning \& Verbal Behavior, 10, $1-12$.

Pillemer, D. B. (1998). Momentous events, vivid memories. Cambridge, MA: Harvard University Press.

Porter, S., Yuille, J. C., \& Lehman, D. R. (1999). The nature of real, implanted and fabricated memories for emotional childhood events: Implications for the false memory debate. Law \& Human Behavior, 23, 517-538.

READ, J. D., \& LindSAY, D. S. (2000). “Amnesia” for summer camps and high school graduation: Memory work increases reports of prior periods of remembering less. Journal of Traumatic Stress, 13, 129-147.

SINGER, J. A., \& BLUCK, S. (2001). New perspectives on autobiographical memory: The integration of narrative processing and autobiographical reasoning. Review of General Psychology, 5, 91-99.

TVersKy, A., \& Kahneman, D. (1973). Availability: A heuristic for judging frequency and probability. Cognitive Psychology, 5, 207232.

Vornik, L. A., Sharman, S. J., \& Garry, M. (2003). The power of the spoken word: Sociolinguistic cues influence the misinformation effect. Memory, 11, 101-109.

WADE, K. A. (2003). [False memory reports categorized using Hyman and Billings' (1998) false memory categories]. Unpublished raw data.

Wade, K. A., Garry, M., Read, J. D., \& Lindsay, D. S. (2002). A picture is worth a thousand lies: Using false photographs to create false childhood memories. Psychonomic Bulletin \& Review, 9, 597-603.

Whittlesea, B. W. A. (1993). Illusions of familiarity. Journal of Experimental Psychology: Learning, Memory, \& Cognition, 19, 12351253.

Wilson, T. D., \& LaFleur, S. J. (1995). Knowing what you'll do: Effects of analyzing reasons on self-prediction. Journal of Personality \& Social Psychology, 68, 21-35. 
Wilson, T. D., \& Schooler, J. W. (1991). Thinking too much: Introspection can reduce the quality of preferences and decisions. Journal of Personality \& Social Psychology, 60, 181-192.

Winkielman, P., SchWarz, N., \& Belli, R. F. (1998). The role of ease of retrieval and attribution in memory judgments: Judging your memory as worse despite recalling more events. Psychological Science, 9 , $\underline{124-126 .}$

\section{NOTES}

1. We did not counterbalance the medium of Event 4. Had we done so, half of the subjects would have seen all true events in one medium and the false event in the other. Given that subjects tended to react to the false event as though it were surprising, we did not want to confound the surprising nature of the event with the medium in which it was presented.

2. Lindsay and colleagues likened their memories category to what others (Hyman \& Billings, 1998; Porter, Yuille, \& Lehman, 1999) have called clear memories and their images category to partial false memories. When we coded our data according to Hyman et al.'s (1995) criteria, we found the same pattern of results. However, the Lindsay et al. (2004) categories do not always map neatly onto the Hyman et al. categories (Wade, 2003).

(Manuscript received October 22, 2003; revision accepted for publication May 28, 2004.) 